\title{
Paenibacillus apiarius sp. nov.
}

\author{
L. K. NAKAMURA* \\ Microbial Properties Research, National Center for Agricultural Utilization \\ Research, Agricultural Research Service, U.S. Department \\ of Agriculture, Peoria, Illinois 61604
}

\begin{abstract}
The name "Bacillus apiarius" Katznelson 1955 was not included on the Approved Lists of Bacterial Names and thus lost standing in bacterial nomenclature. The genetic homogeneity of " $B$. apiarius" strains was assessed by determining their $\mathrm{G}+\mathrm{C}$ contents by the buoyant density method and by measuring the levels of DNA relatedness by spectrophotometric reassociation procedures. The $G+C$ contents of the 15 strains examined, ranged from 52 to $54 \mathrm{~mol} \%$. DNA reassociation revealed the presence of two clusters, each with high levels of intragroup relatedness ( 60 to $100 \%$ ). One cluster consisted of six strains highly related to Bacillus thiaminolyticus, and the other consisted of nine strains related to the designated type strain of "B. apiarius." The strains in the second cluster were not closely related genetically to the type strains of organisms frequently associated with honey bees (namely, Paenibacillus alvei, Paenibacillus larvae, Bacillus laterosporus, and Paenibacillus pulvifaciens). The " $B$. apiarius" strains in the second cluster were also phenotypically homogeneous and distinguishable from the previously described species. Comparative analyses of the 16S rRNA gene DNA sequence showed that the proper phylogenetic position of the second cluster was in the genus Paenibacillus. These findings justify the proposal of a new species with the name Paenibacillus apiarius. The type strain is NRRL NRS-1438.
\end{abstract}

In 1955, Katznelson (9) described the species "Bacillus apiarius" based on two isolates obtained from honeybee larvae. In their studies, Gordon et al. (5) decided that characterizations based on two strains were not dependable and only provisionally recognized this species. "B. apiarius" was listed in Bergey's Manual of Systematic Bacteriology (3), with the reservation that more work was needed to establish its status as a distinct species. Presumably because the description of the species was based on only a few strains, the name " $B$. apiarius" was excluded from the Approved Lists of Bacterial Names (18) and, consequently, lost standing in bacterial nomenclature.

The unique habitat, biochemical characteristics, and spore morphology of " $B$. apiarius" suggest that it might be a distinct species. This work was therefore undertaken to determine the taxonomic position of " $B$. apiarius" based on the results of DNA relatedness analyses, 16S rRNA gene DNA sequence determinations, and extensive phenotypic characterization experiments. On the basis of the findings of this study, the new species Paenibacillus apiarius is proposed.

\section{MATERIALS AND METHODS}

Organisms. Table 1 shows the " $B$. apiarius" strains used in this study. In addition, the following type strains were used: Paenibacillus alvei NRRL B-383, Paenibacillus lanae NRRL B-2605, Bacillus laterosporus NRRL NRS-314, Paenibacillus pulvifaciens NRRL B-3685, and Bacillus thiaminolyticus NRRL B-4156.

TABLE 1. "B. apiarius" strains examined in this study

\begin{tabular}{|c|c|c|c|c|}
\hline Strain & $\begin{array}{l}\text { Designation } \\
\text { as received }\end{array}$ & Source $^{a}$ & $\begin{array}{c}\mathrm{G}+\mathrm{C} \text { content } \\
(\mathrm{mol} \%)\end{array}$ & History \\
\hline \multicolumn{5}{|l|}{ Cluster 1 strains } \\
\hline NRRL NRS-1768 & NRS-1768 & 1 & 54 & M. Gilliam; isolated from honeybee larva; "B. apiarius" \\
\hline NRRL NRS-1769 & NRS-1769 & 1 & 53 & M. Gilliam; isolated from honeybee larva; "B. apiarius" \\
\hline NRRL NRS-1770 & NRS-1770 & 1 & 54 & M. Gilliam; isolated from honeybee larva; " $B$. apiarius" \\
\hline NRRL NRS-1771 & NRS-1771 & 1 & 53 & M. Gilliam; isolated from honeybee larva; " $B$. apiarius" \\
\hline NRRL NRS-1772 & NRS-1772 & 1 & 53 & M. Gilliam; isolated from honeybee larva; " $B$. apiarius" \\
\hline NRRL NRS-1773 & NRS-1773 & 1 & 54 & M. Gilliam; isolated from honeybee larva; "B. apiarius” \\
\hline \multicolumn{5}{|l|}{ Cluster 2 strains } \\
\hline NRRL B-3678 & & 2 & 54 & H. Katznelson; "B. apiarius" \\
\hline NRRL B-4187 & $8-20-62$ & 3 & 54 & H. Katznelson; isolated from dead honeybee; "B. apiarius" \\
\hline NRRL B-4188 & $9-17-71$ & 3 & 53 & H. Katznelson; isolated from dead honeybee; "B. apiarius" \\
\hline NRRL B-4299 & 1303 & 4 & 53 & "B. apiarius" \\
\hline NRRL B-4303 & 1304 & 4 & & "B. apiarius" \\
\hline NRRL NRS- $1438^{\mathrm{T}}$ & NRS-1438 & 1 & 52 & H. Katznelson BX3; isolated from honeybee larva; "B. apiarius" \\
\hline NRRL NRS-1439 & NRS-1439 & 1 & 52 & H. Katznelson BX5; isolated from honeybee larva; " $B$. apiarius" \\
\hline NRRL NRS-1577 & NRS-1577 & 1 & 53 & W. C. Haynes; "B. apiarius" \\
\hline NRRL NRS-1578 & NRS-1578 & 1 & 52 & W. C. Haynes; "B. apiarius” \\
\hline
\end{tabular}

${ }^{a} 1$, N. R. Smith Bacillus collection maintained by R. E. Gordon, Rutgers University, New Brunswick, N.J.; 2, T. A. Gochnauer, Entomology Research Institute, Ottawa, Canada; 3, J. D. Hitchcock, U.S. Honeybee Research Station, Laramie, Wyo.; 4, R. J. Norris, University of Leeds, Leeds, England.

* Mailing address: National Center for Agricultural Utilization Research, 1815 North University Street, Peoria, IL 61614. 
The Agricultural Research Service Culture Collection (NRRL) at the National Center for Agricultural Utilization Research maintains these strains. Each NRRL designation includes the prefix B-, which designates strains acquired directly from individuals or strains isolated at the National Center for Agricultural Utilization Research, or the prefix NRS-, which designates strains obtained from the Bacillus collection of N. R. Smith deposited in the Agricultural Research Service Culture Collection by R. E. Gordon. Working stock cultures were incubated at $28^{\circ} \mathrm{C}$ on nutrient agar amended with $5 \mathrm{mg}$ of $\mathrm{MnSO}_{4} \cdot \mathrm{H}_{2} \mathrm{O}$ per liter until sporulation occurred and then were stored at $4^{\circ} \mathrm{C}$.

DNA isolation, $\mathbf{G}+\mathbf{C}$ contents, and DNA reassociation. The organisms used for DNA isolation were grown to the mid- to late-logarithmic phase (where microscopic examination showed an absence of sporulation) in TGY broth (6) at $28^{\circ} \mathrm{C}$ on a rotary shaker $(200 \mathrm{rpm})$, and the cells were harvested by centrifugation at $5^{\circ} \mathrm{C}$.

DNA was extracted and purified by a modification of the method of Marmur (13). The modification entailed the use of $\mathrm{CsCl}$ gradient ultracentrifugation to purify the DNA preparations (12). Consistent values of 1.8 to 1.9 and 2.0 to 2.3 for the ratios of $A_{260}$ to $A_{280}$ and the ratios of $A_{260}$ to $A_{230}$, respectively, confirmed the high quality of each DNA preparation. Melting curves showing hyperchromicities ranging from 38 to $40 \%$ (14) corroborated the absorbance ratio observations.

In a previous publication (14), the protocol used for spectrophotometric estimation of the extent of DNA reassociation was described. The extent of reassociation was calculated by the equation of De Ley et al. (4).

The U.C. Cluster procedure of the PC-SAS version (SAS Institute, Inc., Cary, N.C.) facilitated computer-aided clustering of DNA relatedness data based on an unweighted pair group arithmetic average algorithm (19). SAS/GRAPH, in which the SAS macro GRAFTREE written and provided by Dan Jacobs, University of Maryland, was used, permitted computer-aided generation of dendrograms.

16S rRNA gene sequencing. A 16S rRNA gene DNA fragment of strain NRRL NRS-1438 $(\mathrm{T}=$ type strain) that corresponds to positions 9 to 1510 of Escherichia coli $16 \mathrm{~S}$ rRNA was amplified by PCR, using purified DNA and a primer combination consisting of 5'-AGAGTTTGATCCTGGCTCAG-3' (forward primer 27f [10]) and 5'-TACGG(CT)TACCTTGTTACGACTT-3' (reverse primer 1492r (10]). The amplification products were purified with a GENECLEAN II kit (Bio 101, La Jolla, Calif.) and were sequenced with a Prism ABI dideoxy terminator cycle sequencing kit manufactured by Applied Biosystems, Ltd. The protocols used were those recommended by the manufacturer. Sequences were determined with the automated Applied Biosystems DNA sequencer. The following primers cited by Lane (10) were used for sequence analyses: primers $27 \mathrm{f}, 530 \mathrm{f}, 1114 \mathrm{f}, 1406 \mathrm{f}, 109 \mathrm{rl}, 342 \mathrm{r}, 685 \mathrm{r} 3,907 \mathrm{r}, 1100 \mathrm{r}$, and $1492 \mathrm{r}$. In addition, two other primers, designated as $304 \mathrm{f}\left(5^{\prime}\right.$-GTAGCCGAC CTGAGAGG-3') and 801f (5'-AACAGGATTAGATACCC-3'), were designed to obtain unambiguous results. The CLUSTAL V (7) program was used to align the 16S rRNA gene DNA sequence generated with sequences of selected members of the family Bacillaceae obtained from GenBank (11). A similarity matrix was constructed from the aligned sequences. Pairwise evolutionary distances were computed from the similarity data by applying the Olsen correction parameter (15) of Jukes and Cantor (8). Preliminary relationships were determined by the neighbor-joining method of Saitou and Nei (16) and the DNA parsimony algorithm, using the DNAPARS program. The parsimony analysis revealed six equally parsimonious best trees. The robustness of the topologies was evaluated by bootstrap analysis (SEQBOOT program) through 100 bootstrap replications. The DNAML program was used to generate a maximum-likelihood tree (see Fig. 2) to which bootstrap values of more than $60 \%$ were applied. The DNAPARS SEQBOOT, and DNAML programs are part of the PHYLIP, version 3.55c, software package (J. Felsenstein, University of Washington, Seattle).

Characterization. Strain characterization was carried out as described previously $(5,14)$. Whole-cell fatty acid profiles were determined by the MIDI system of Sasser (17).

Nucleotide sequence accession number. The GenBank accession number for the NRRL NRS $-1438^{\mathrm{T}}$ 16S rRNA gene DNA sequence is U49247.

\section{RESULTS}

The results of the DNA relatedness analyses segregated the "B. apiarius" strains into two clusters, as shown in Table 2 . The members of one cluster, consisting of nine strains, showed intragroup levels of relatedness ranging from 93 to $100 \%$, and the members of the second cluster, consisting of six strains, exhibited values ranging from 60 to $100 \%$. In the cluster consisting of six strains, NRRL B-4156 is the type strain of $B$. thiaminolyticus. The dendrogram in Fig. 1 clearly shows the segregation of the " $B$. apiarius" strains into two clusters; cluster 1 contains organisms closely related to $B$. thiaminolyticus, and cluster 2 represents another distinct taxon. The $\mathrm{G}+\mathrm{C}$ contents

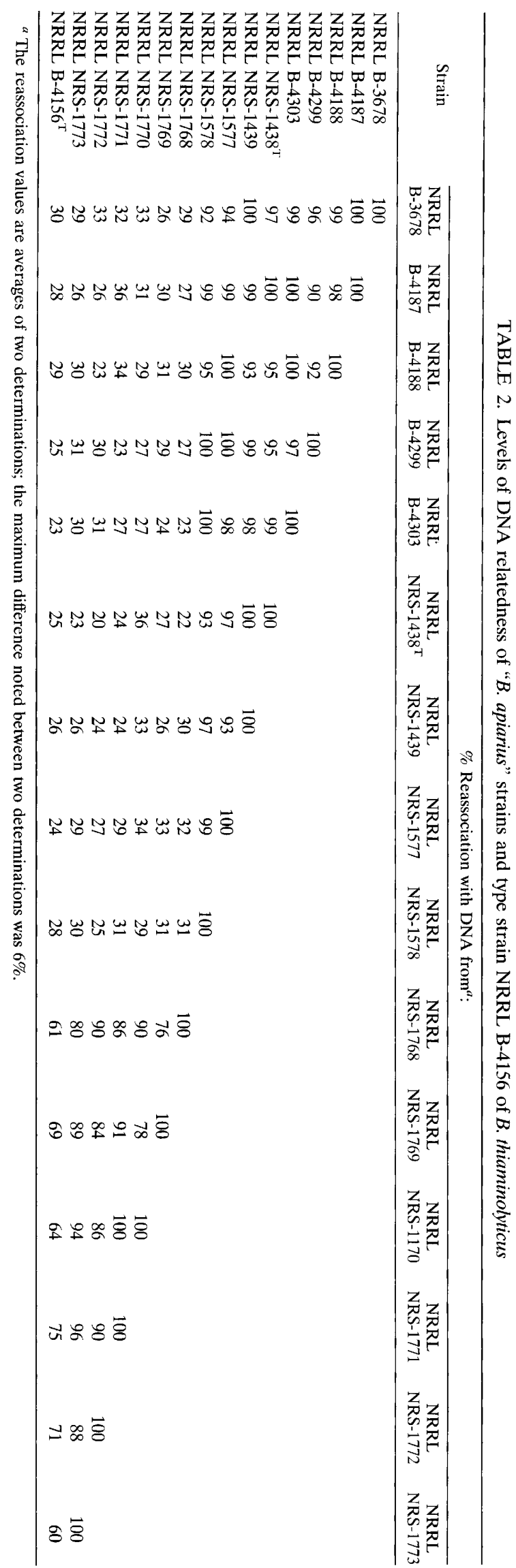




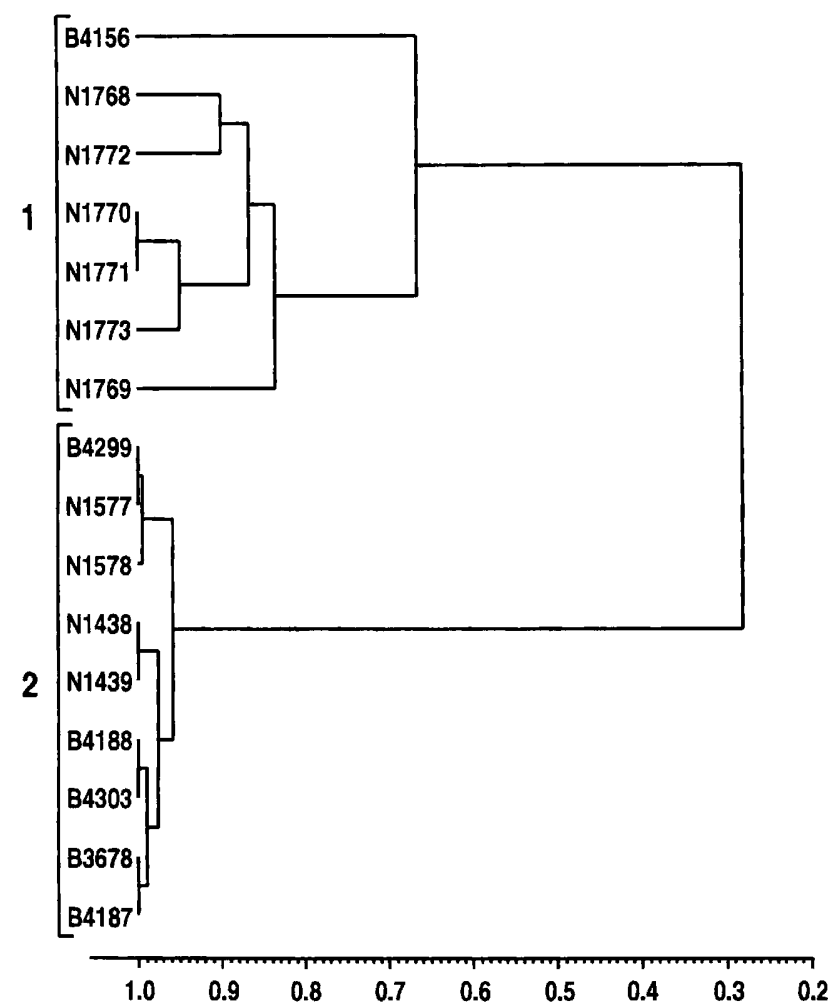

FIG. 1. Dendrogram showing levels of DNA relatedness among "B. apiarius" strains and strain NRRL B-4156, the type strain of B. thiaminolyticus. Clustering was based on unweighted average-linkage clustering. All strain designations are NRRL designations.

of all of the strains based on buoyant density determinations ranged from 52 to $54 \mathrm{~mol} \%$.

As is shown in Table 3, low levels of DNA relatedness (range, 20 to $31 \%$ ) demonstrated that the cluster 2 strains are only distantly related to species frequently associated with honeybees or their hives (namely, $P$. alvei, $P$. larvae, B. laterosporus, and $P$. pulvifaciens).

The $16 \mathrm{~S}$ rRNA gene DNA of NRRL NRS $-1438^{\mathrm{T}}$ was sequenced to determine the phylogenetic position of this strain among the aerobic members of the Bacillaceae. A total of 12 primers were used, and a 1,489-base sequence was obtained. The extents of sequence similarity of the $16 \mathrm{~S}$ rRNAs of $B$. apiarius NRRL NRS-1438 ${ }^{\mathrm{T}}$ and selected species belonging to the genera Bacillus (groups 1, 2, 4, and 5 as defined by Ash et al. [1]), Paenibacillus (formerly group $3[1,2]$ ), Alicyclobacillus, Saccharococcus, Sporolactobacillus, and Sporosarcina are shown in Table 4. Similarity values of 90.5 to $95.5 \%$ indicated that NRRL NRS-1438 ${ }^{\mathrm{T}}$ was most closely related to members of the genus Paenibacillus. Furthermore, NRRL NRS-1438 ${ }^{\mathrm{T}}$ was equidistant from Bacillus groups 1,2, and 4; the average similarity values were $87.1 \%$ for members of group 1 (Bacillus cereus, Bacillus circulans, Bacillus coagulans, Bacillus smithii, and Bacillus subtilis), $87.0 \%$ for group 2 members (Bacillus globisporus, Bacillus insolitus, Bacillus sphaericus, and Sporosarcina ureae), and $87.2 \%$ for group 4 members (Bacillus brevis, Bacillus laterosporus, and Bacillus aneurinolyticus). With similarity values of $85.6,86.0$, and $83.5 \%$, respectively, members of group 5 (Bacillus kaustophilus, Bacillus stearothermophilus, $B a-$ cillus thermoglucosidasius, and Saccharococcus thermophilus), Sporolactobacillus inulinus, and Alicyclobacillus cycloheptanicus were more distantly related to NRRL NRS $-1438^{\mathrm{T}}$.
On the basis of their sequences Paenibacillus species and NRRL NRS $-1438^{\mathrm{T}}$ were placed in a robust (bootstrap values, $100 \%$ ) monophyletic group corresponding to the genus Paenibacillus (Fig. 2). NRRL NRS-1438 ${ }^{\mathrm{T}}$ formed a monophyletic group with $P$. alvei, as determined by all methods. The clustering of NRRL NRS-1438 $8^{\mathrm{T}}$ with $P$. alvei was supported by the results of the bootstrap analyses at a confidence level of $100 \%$.

Phenotypically, the cluster 2 organisms are gram-variable, facultatively anaerobic, mesophilic, motile rods that produce ellipsoidal spores in swollen sporangia, hydrolyze starch and casein, and ferment a wide range of mono- and disaccharides. The phenotypic characteristics of cluster 2 strains, $P$. alvei, $P$. larvae, $B$. laterosporus, $P$. pulvifaciens, and $B$. thiaminolyticus are compared in Table 5 . The cluster 2 strains were clearly distinct from the other recognized species.

Significant differences in the levels of several fatty acids allowed differentiation of cluster 2 strains from $P$. alvei, $P$. larvae, B. laterosporus, $P$. pulvifaciens, and B. thiaminolyticus (Table 6). Specifically, differences in the levels of the 14:0, 15:0 anteiso, and 16:0 fatty acids differentiated cluster 2 from $P$. alve $i$; the fatty acids that differentiated cluster 2 and $P$. larvae were the 14:0, 15:0 anteiso, 16:0 iso, and 16:0 fatty acids; the fatty acids that separated cluster 2 and $B$. laterosporus were the 14:0 iso, 15:0 iso, 16:0 iso, 16:1 $\omega 11$ cis, $17: 1$ iso $\omega 10$ cis, and 17:0 anteiso fatty acids; the fatty acids that separated cluster 2 and $P$. pulvifaciens were the 15:0 anteiso and 15:0 fatty acids; and the fatty acids that distinguished cluster 2 and $B$. thiaminolyticus were the 15:0 iso, 15:0 anteiso, 16:0 iso, 16:1 $\omega 11$ cis, 16:0, $17: 0$ iso, and 17:0 anteiso fatty acids.

The photomicrograph in Fig. 3 visually confirmed a previous written account (3) in which the spore coat of " $B$. apiarius" was described as being ridged, rectangular in outline, and unusually thick.

\section{DISCUSSION}

Because of their similar phenotypic characteristics, many $B$. thiaminolyticus strains have apparently been erroneously identified as " $B$. apiarius." The DNA relatedness data compiled in this study show that " $B$. apiarius" is a conglomerate of two genetically distinct taxa, one of which is B. thiaminolyticus and the other of which is designated cluster 2. Small-subunit rRNA sequence data revealed that cluster 2 is a member of the genus Paenibacillus, which includes species associated with honeybees or their hives $(P$. alvei, $P$. larvae, and $P$. pulvifaciens). The cluster 2 organisms have many of the phenotypic characteristics of the genus Paenibacillus, including a variable Gram reaction, production of ellipsoidal spores in swollen sporangia, facultatively anaerobic growth at mesophilic temperatures, hydrolysis of complex molecules, and fermentation of a wide range of sugars. Like other Paenibacillus species, the

TABLE 3. Levels of DNA relatedness of some cluster 2 strains ("B. apiarius"), P. alvei, P. larvae, B. laterosporus, and $P$. pulvifaciens

\begin{tabular}{|c|c|c|c|}
\hline \multirow[b]{2}{*}{ Strain } & \multicolumn{3}{|c|}{$\%$ Reassociation with DNA from ${ }^{a}$ : } \\
\hline & $\begin{array}{c}\text { NRRL } \\
\text { NRS-1438 }\end{array}$ & $\begin{array}{c}\text { NRRL } \\
\text { NRS-1439 }\end{array}$ & $\begin{array}{l}\text { NRRL } \\
\text { B-4299 }\end{array}$ \\
\hline P. alvei NRRL B-383 ${ }^{\mathrm{T}}$ & 20 & 23 & 26 \\
\hline P. larvae NRRL B-2605 & 24 & 28 & 27 \\
\hline B. laterosporus NRRL NRS-314 ${ }^{\mathrm{T}}$ & 30 & 29 & 31 \\
\hline P. pulvifaciens NRRL B-3685 ${ }^{\mathrm{T}}$ & 24 & 24 & 27 \\
\hline
\end{tabular}

a The reassociation values are averages of two determinations; the maximum difference noted between determinations was $6 \%$. 


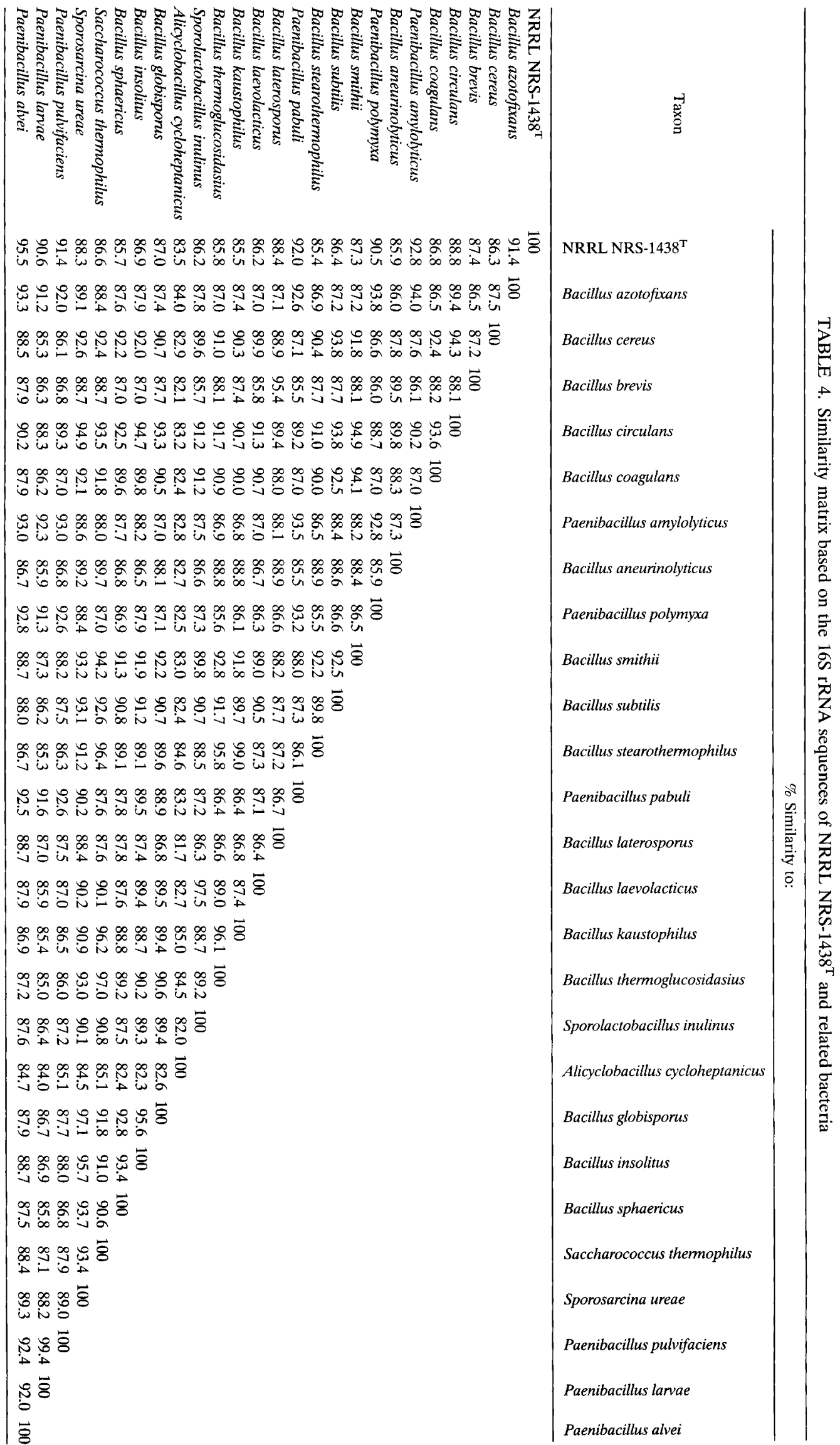



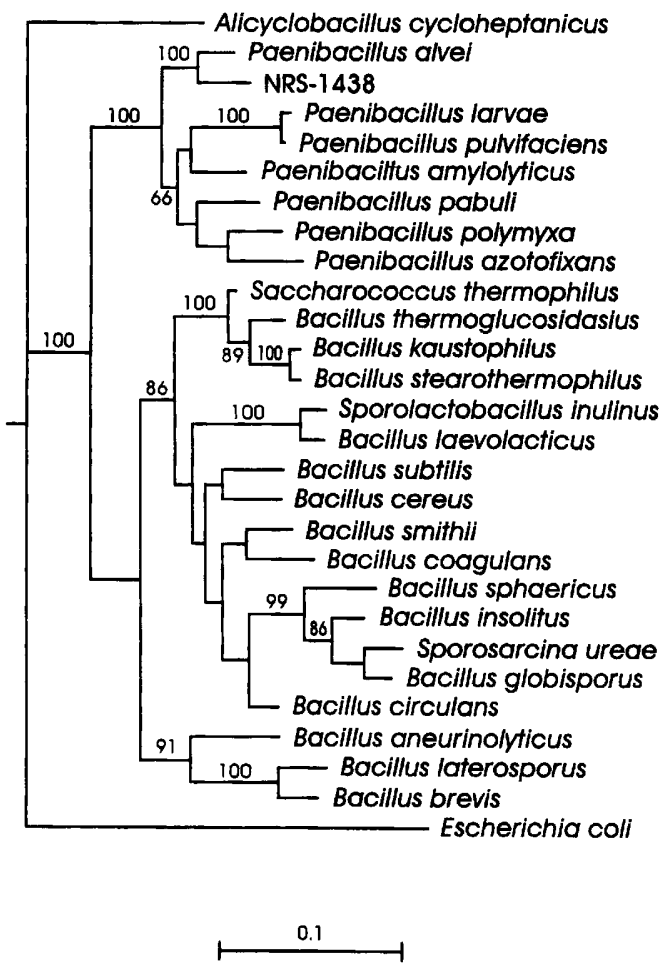

FIG. 2. Tree showing the phylogenetic position of NRRL NRS-1438 ${ }^{\mathrm{T}}$ among selected bacteria belonging to the family Bacillaceae. The tree, which is rooted by using $E$. coli as the outgroup, was generated by maximum-likelihood method DNAML. Trees generated by the neighbor-joining method and by parsimony analysis had similar topologies. Bootstrap values ( 100 data sets) were determined by performing a parsimony analysis. Bar $=0.1$ accumulated change per nucleotide.

predominant cellular fatty acid is the 15:0 anteiso fatty acid. The $\mathrm{G}+\mathrm{C}$ contents of the cluster 2 strains fall within the range exhibited by members of the genus Paenibacillus (40 to 54 mol\%). Although the results of the sequence analysis show that there is a close phylogenetic relationship between NRRL NRS $-1438^{\mathrm{T}}$ and $P$. alvei, the cluster 2 organisms are only distantly related genetically to $P$. alvei. The cluster 2 organisms and the other honeybee-associated Paenibacillus species are also only distantly related. Likewise, the cluster 2 strains and the honeybee-associated species $B$. laterosporus are not closely related genetically.
The cluster 2 organisms are also phenotypically distinct from the organisms obtained from honeybee environs mentioned above. The following characteristics are some outstanding characteristics that are not found in cluster 2 strains: $P$. alvei produces indole and dihydroxyacetone; $P$. larvae is pathogenic to honeybees and does not produce catalase; $B$. laterosporus has a distinct canoe-shaped sporangium; $P$. pulvifaciens does not utilize citrate or hydrolyze starch; and $B$. thiaminolyticus produces indole and decomposes thiamine. Dissimilar cellular fatty acid compositions also indicate that " $B$. apiarius" is distinct from the currently recognized honeybee-associated species.

All strains of " $B$. apiarius" produce thick-walled spores that are rectangular in outline and are unlike the ellipsoidal spores of $B$. thiaminolyticus and other species. This unusual morphology is clearly different from the canoe-shaped sporangia associated with $B$. laterosporus.

The data obtained in this study justify placing cluster 2 in the genus Paenibacillus and recognizing it as a phenotypically and genotypically distinct species, for which the name Paenibacillus apiarius is proposed. Strain NRRL NRS-1438 is the type strain of this species. A description of the type strain is given below.

Description of Paenibacillus apiarius. Paenibacillus apiarius (a.pi.a'ri.us. L. adj. apiarius, relating to bees).

Rods that are 0.7 to 0.8 by 3.0 to $5.0 \mu \mathrm{m}$, as determined from a photomicrograph. Gram staining is variable. Motile. Spores have thick walls, appear to be rectangular, and are produced in swollen sporangia.

Agar colonies are nonpigmented, translucent, thin, smooth, circular, and entire, and the average diameter is about $1.0 \mathrm{~mm}$ after $24 \mathrm{~h}$ of incubation on TGY agar at $28^{\circ} \mathrm{C}$.

Catalase is produced. Oxidase negative.

Facultatively anaerobic.

Acetylmethylcarbinol, dihydroxyacetone, indole, and $\mathrm{H}_{2} \mathrm{~S}$ are not produced. The $\mathrm{pH}$ in Voges-Proskauer broth (test for acetylmethylcarbinol production) ranges from 4.4 to 5.4.

Nitrate is reduced to nitrite.

Starch, casein, tyrosine, and urea are hydrolyzed. Tween 80 and egg yolk lecithin are not decomposed. Lysine, ornithine, arginine, and phenylalanine are not decomposed.

Citrate is utilized; propionate is not utilized.

Growth occurs at $\mathrm{pH} 5.7$, in the presence of $0.001 \%$ lysozyme, and in the presence of $5 \% \mathrm{NaCl}$; growth is inhibited by $7 \% \mathrm{NaCl}$

The optimum growth temperature is $28^{\circ} \mathrm{C}$; the maximum temperature is $40^{\circ} \mathrm{C}$; and the minimum temperature is $15^{\circ} \mathrm{C}$.

TABLE 5. Phenotypic comparison of cluster 2 (“B. apiarius"), P. alvei, P. larvae, B. laterosporus, $P$. pulvifaciens, and B. thiaminolyticus

\begin{tabular}{|c|c|c|c|c|c|c|}
\hline Characteristic & Cluster 2 & P. alvei & P. larvae & B. laterosporus & P. pulvifaciens & B. thiaminolyticus \\
\hline Catalase & $+^{a}$ & + & - & + & + & + \\
\hline Acetylmethylcarbinol production & - & + & - & - & - & - \\
\hline Dihydroxyacetone production & - & + & - & - & - & - \\
\hline Indole production & - & + & - & $\mathrm{v}$ & - & + \\
\hline Citrate utilization & + & - & - & - & - & + \\
\hline Nitrate reduction to nitrite & + & - & $\mathrm{v}$ & + & + & + \\
\hline Tyrosine decomposition & + & $\mathbf{v}$ & - & + & - & + \\
\hline Casein hydrolysis & + & + & + & + & + & + \\
\hline Starch hydrolysis & + & + & - & - & - & + \\
\hline Acid production from arabinose & - & - & - & - & - & $\mathrm{v}$ \\
\hline Acid production from mannitol & - & - & $\mathrm{v}$ & + & + & $\mathrm{v}$ \\
\hline Growth at pH 5.6 & - & + & - & - & - & - \\
\hline Growth at $50^{\circ} \mathrm{C}$ & - & - & - & + & - & - \\
\hline $\mathrm{G}+\mathrm{C}$ content $(\mathrm{mol} \%)$ & $52-54$ & $44-47$ & 50 & $40-42$ & $44-46$ & $52-54$ \\
\hline
\end{tabular}

\footnotetext{
${ }^{a}+$, positive reaction; - , negative reaction; $\mathrm{v}$, variable reaction.
} 
TABLE 6. Cellular fatty acid compositions of cluster 2 ("B. apiarius") and selected Bacillus and Paenibacillus species

\begin{tabular}{|c|c|c|c|c|c|c|}
\hline \multirow{2}{*}{ Fatty acid } & \multicolumn{6}{|c|}{$\% \mathrm{in}^{a}:$} \\
\hline & Cluster 2 & P. alvei & P. larvae & B. laterosporus & P. pulvifaciens & B. thiaminolyticus \\
\hline $14: 0$ iso & $0.35 \pm 0.50^{b}$ & $0.58 \pm 0.82$ & $0.69 \pm 0.71$ & $7.24 \pm 1.82^{c}$ & $\mathrm{ND}^{d}$ & $0.12 \pm 0.29$ \\
\hline $14: 0$ & $1.11 \pm 0.62$ & $2.28 \pm 0.13$ & $3.31 \pm 0.50$ & $1.43 \pm 0.11$ & $1.18 \pm 0.16$ & $1.93 \pm 0.62$ \\
\hline $15: 0$ iso & $14.15 \pm 3.18$ & $11.09 \pm 0.97$ & $10.51 \pm 1.61$ & $34.27 \pm 12.71$ & $15.90 \pm 1.11$ & $6.12 \pm 0.68$ \\
\hline 15:0 anteiso & $51.89 \pm 0.01$ & $57.29 \pm 1.97$ & $28.21 \pm 0.87$ & $48.04 \pm 12.60$ & $39.13 \pm 2.73$ & $47.73 \pm 2.52$ \\
\hline $15: 0$ & $0.53 \pm 0.74$ & $0.58 \pm 0.81$ & $1.58 \pm 0.35$ & ND & $6.71 \pm 2.43$ & $0.25 \pm 0.39$ \\
\hline 16:1 $\omega$ cis 9 alcohol & $0.50 \pm 0.70$ & ND & ND & $0.70 \pm 0.50$ & ND & ND \\
\hline $16: 0$ iso & $5.02 \pm 0.72$ & $4.51 \pm 2.47$ & $3.20 \pm 0.59$ & $2.89 \pm 0.79$ & $4.13 \pm 0.73$ & $3.47 \pm 0.69$ \\
\hline 16:1 $\omega 11$ cis & $1.96 \pm 0.38$ & $2.97 \pm 1.73$ & ND & $0.77 \pm 0.54$ & ND & $5.23 \pm 2.17$ \\
\hline $16: 0$ & $3.76 \pm 1.62$ & $8.46 \pm 1.17$ & $27.97 \pm 2.30$ & ND & $8.12 \pm 2.66$ & $11.55 \pm 4.60$ \\
\hline $17: 1$ iso $\omega 10$ cis & $1.84 \pm 0.33$ & ND & ND & $0.62 \pm 0.44$ & ND & $0.82 \pm 0.66$ \\
\hline $17: 0$ iso & $6.39 \pm 0.57$ & $4.35 \pm 1.46$ & $6.91 \pm 0.24$ & $1.05 \pm 0.90$ & $6.77 \pm 0.71$ & $4.32 \pm 0.77$ \\
\hline $17: 0$ anteiso & $10.13 \pm 2.06$ & $7.48 \pm 1.97$ & $9.46 \pm 1.10$ & $1.28 \pm 0.17$ & $12.79 \pm 2.02$ & $16.31 \pm 2.73$ \\
\hline
\end{tabular}

${ }^{a}$ Six strains of each organism were analyzed.

${ }^{b}$ Mean \pm standard deviation.

$c$ Values in boldface type are significantly different $(P<0.05)$ from the cluster 2 values.

${ }^{d} \mathrm{ND}$, not detected.

Acid but no gas is produced from cellobiose, D-galactose, D-glucose, maltose, D-mannose (weak), melibiose, D-ribose (weak), salicin, sucrose, and trehalose. L-Arabinose, D-fructose, lactose, mannitol, L-rhamnose, sorbitol, and D-xylose are not fermented.

The DNA buoyant density ranges from 1.7055 to 1.7075 $\mathrm{g} / \mathrm{cm}^{3}$; the $\mathrm{G}+\mathrm{C}$ content is 52 to $54 \mathrm{~mol} \%$.

Isolated from honeybees, their larvae, and their hives.

Type strain NRRL NRS-1438 has been deposited in the Agricultural Research Service Culture Collection at the National Center for Agricultural Utilization Research in Peoria, Ill.

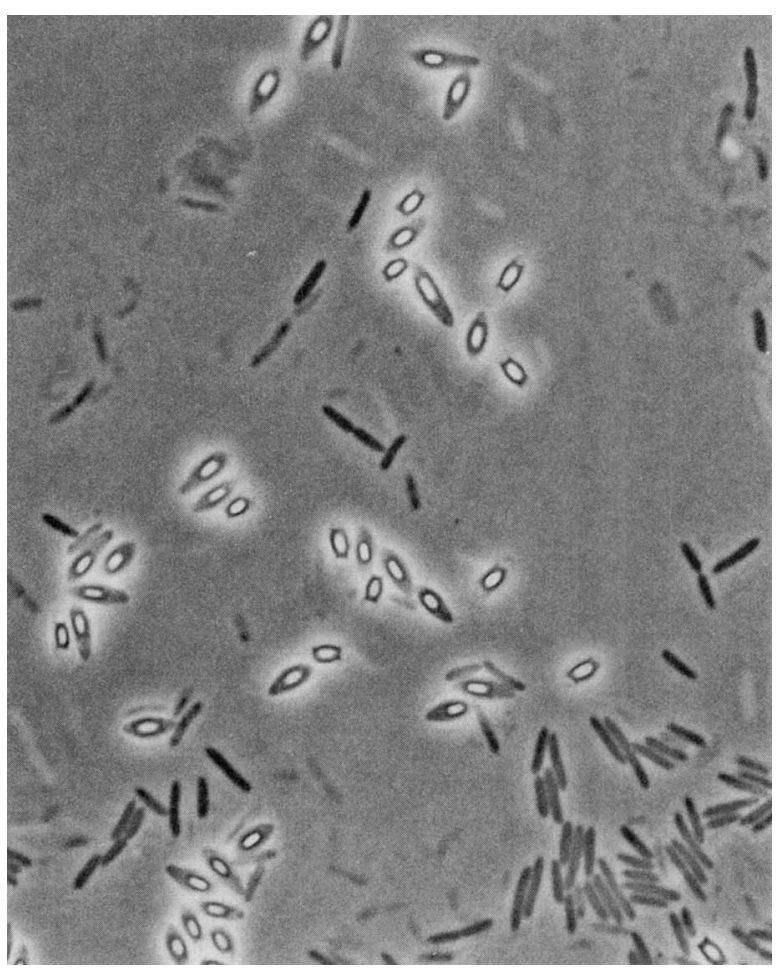

FIG. 3. Phase-contrast photograph of "B. apiarius" NRRL NRS-1438'. Magnification, $\times 1,400$.

\section{ACKNOWLEDGMENTS}

I thank J. Swezey and H. J. Gasdorf for their able technical assistance.

\section{REFERENCES}

1. Ash, C., J. A. E. Farrow, S. Walksbanks, and M. D. Collins. 1991. Phylogenetic heterogeneity of the genus Bacillus revealed by comparative analysis of small-ribosomal RNA sequences. Lett. Appl. Microbiol. 13: 202-206.

2. Ash, C., F. G. Priest, and M. D. Collins. 1993. Molecular identification of rRNA group 3 bacilli (Ash, Farrow, Walksbanks, and Collins) using a PCR probe test. Antonie Leeuwenhoek 64:253-260.

3. Claus, D., and R. C. W. Berkeley. 1986. Genus Bacillus Cohn 1872, p. 1105-1139. In P. H. A. Sneath, N. S. Mair, M. E. Sharpe, and J. G. Holt (ed.), Bergey's manual of systematic bacteriology, vol. 2. Williams \& Wilkins, Baltimore.

4. De Ley, J., H. Cattoir, and A. Reynaerts. 1970. The quantitative measurement of DNA hybridization from renaturation rates. Eur. J. Biochem. 12: 133-142.

5. Gordon, R. E., W. C. Haynes, and C. H.-N. Pang. 1973. The genus Bacillus Agricultural Handbook no. 427. U.S. Department of Agriculture, Washington, D.C.

6. Haynes, W. C., L. J. Wickerham, and C. W. Hesseltine. 1955. Maintenance of cultures of industrially important microorganisms. Appl. Microbiol. 3:361-368.

7. Higgines, D. G., A. J. Bleasby, and R. Fuchs. 1992. CLUSTAL V: improved software for multiple sequence alignment. Comput. Appl. Biosci. 8:189-191.

8. Jukes, T. H., and C. R. Cantor. 1969. Evolution of protein molecules, p. 21-132. In H. N. Munro (ed.), Mammalian protein metabolism. Academic Press, New York.

9. Katznelson, H. 1955. Bacillus apiarius n. sp., an aerobic spore-forming organism isolated from honey bee larvae. J. Bacteriol. 70:635-636.

10. Lane, D. L. 1991. 16S/23S rRNA sequencing, p. 115-175. In E. Stackebrandt and M. Goodfellow (ed.), Nucleic acid techniques in bacterial systematics. John Wiley \& Sons, New York.

11. Larsen, N. A., G. J. Olsen, B. L. Maidak, M. J. McCaughey, R. Overbeek, T. J. Marsh, and C. R. Woese. 1993. The Ribosomal Database Project. Nucleic Acids Res. 21:3021-3023.

12. Maniatis, T., E. F. Fritsch, and J. Sambrook. 1982. Molecular cloning: a laboratory manual. Cold Spring Harbor Laboratory, Cold Spring Harbor, N.Y.

13. Marmur, J. 1961. A procedure for the isolation of deoxyribonucleic acid from microorganisms. J. Mol. Biol. 3:208-218.

14. Nakamura, L. K., and J. Swezey. 1983. Taxonomy of Bacillus circulans Jordan 1890: base composition and reassociation of deoxyribonucleic acid. Int. J. Syst. Bacteriol. 33:46-52.

15. Olsen, G. J. 1988. Phylogenetic analysis using ribosomal RNA. Methods Enzymol. 164:793-812.

16. Saitou, N., and M. Nei. 1987. The neighbor-joining method: a new method for reconstructing phylogenetic trees. Mol. Biol. Evol. 4:406-425.

17. Sasser, M. 1990 . Identification of bacteria by gas chromatography of cellular fatty acids. Technical Note 101. Microbial ID, Inc., Newark, Del.

18. Skerman, V. B. D., V. McGowan, and P. H. A. Sneath (ed.). Approved lists of bacterial names. Int. J. Syst. Bacteriol. 30:225-420.

19. Sneath, P. H. A., and R. R. Sokal. 1973. Numerical taxonomy. W. H. Freeman and Co., San Francisco. 